\title{
Research on Impacts of Bribery on Different Business Sectors
}

\author{
Yixian Wang \\ ${ }^{1}$ Bachelor of Arts - Economics, University of Alberta,116 St \& 85 Ave, Edmonton, AB, T6G 2R3, Canada. \\ *Corresponding author.Email: yixian1@ualberta.ca
}

\begin{abstract}
The prevalence of corruption such as bribery today has disrupted the normal economic order, caused waste of resources, loss of tax revenue, and serious problems such as government corruption and inefficiency. This dissertation will study the effects or impacts of bribery on various business sectors in the economy. It compares the construction sector, manufacturing sector and the service sector. Different factors play a greater role in different sectors where political influence plays the major role. This research put into use quantitative methods research method, secondary and qualitative methods which gave the researcher a clear understanding and background of the study. These methods made sure that the researchers were well equipped when doing the research. It is clear from the research findings that the sector of construction benefits more from the action of bribery because it has some benefits that come along with it. The sector of manufacturing is undermined however by bribery because most officials of the state are linked to it. It can be concluded that the research study came up with findings that the action of taking and giving bribes undermines the general performances of various sectors in a country's economy. The research also, concluded that the level of investments is greatly affected by the level of bribe in the economy hence the economy is derailed by the bribery levels of the economy.
\end{abstract}

Keywords: Bribery, Corruption, Bribery environment, Business sectors

\section{INTRODUCTION}

The act of giving and taking bribes affects both the business activities of the economy and also the general working morale of their employees. Bribery is viewed by many as a tool that can be used to boost the growth of individual businesses. Due to the bribery activities, losses can be encountered in the economy or business sectors and these may lead to demoralization of employees.

Many countries experience bigger bribery related cases and this is because of the weak formulation and implementation of policies. According to Rontos, et al. 2019, the presence of weak policies makes bribery activities emerge and slow down the economic progress of an economy. Regardless of these, the act of bribery cannot be termed as a national problem because it also affects the international levels also. The World Bank, the IMF, the UN and other international bodies have always felt the impacts of bribery and its related activities in their various organizations.

This research dissertation investigates and establishes the effects of bribery on economy so as to add more knowledge to theories that already exist on the same. This general knowledge will therefore be of help in coming up with more ways which help business to shun from bribery. The research questions, therefore, need to look into the effects of bribery on various sectors of a country's economy.

\section{LITERATURE REVIEW}

\subsection{Grease Wheel and Local Bribery Environment}

The environments of the institutions that control a country's economy have a direct impact on its economic level in one way or another. The hypothesis of "grease the wheel" has influences on bribery levels of an economy [14]. In areas where most businesses need legal permits for them to operate becomes red points for bribery activities. This is especially if these areas are surrounded by officials who are greedy. These greedy officials who are in charge always ask for money for any service that they give. Areas with different business types will therefore experience different bribery levels. The 
bribery levels differ according to the nature of business activities for which you are trying to seek favor. For example, someone who wants to process five licenses hand in hand with legal documents in order to start a business shall in an away gets involved in bribery cases at different levels as compared to another who wants a single license from the same industry. Because these firms generally depend on officials of the government in obtaining these permits for their business, they will therefore be forced into paying higher bribes as compared to micro businesses

The "grease the wheel" hypothesis works in a way that ensures companies obtain more favors from government than other companies. Companies that encourage bribery will be competing with companies that do not encourage the same. Due to these, the firms that encourage bribery will be a step ahead of the other firms that do not encourage these act of bribery.

\subsection{Political and Economic Environment Influence on Bribery and its Impacts on Businesses}

The levels of restrictions of economic activities in a country point out corruption levels [15]. That is, when principles and the rules that are being put to place are tiresome and so tight, people tend to bribe so that they can avoid following the required processes. Bribing reduces the time which is needed in accessing various services from officials of the government in enhancing their businesses. Potential investors are always willing to pay higher officials in various offices so as to avoid various restrictions that have always been put into place in getting various services. The bribery levels will be quite higher in situations where the government's s high officials have the powers and mandate of the economy's decision making.

\section{RESEARCH METHODOLOGY}

\subsection{Research design}

Research design entails the plans for the research that links up the steps from the larger assumptions down to specific methods of data collection, analysis and, interpretation [11]. This research study contains both qualitative data sets and quantitative data sets. The correct design selection to put into use in data analysis and also collection provides results that are accurate and lowers the chances of making errors. The qualitative design helps the researchers in providing an insight to the research problems.

This research study is made up of three objectives. The first two objectives try to analyze effects of bribery activities on various business sectors in the economy after putting into use the previous literature. The previous research studies analyzed the impacts of bribery to different business sectors. The research objectives will thus be met by conducting in-depth reviews of academic journals that investigate the effects of bribery on businesses in the economy. The articles gotten from journals shall be used in doing comparisons of the findings. The comparison that will be obtained from the research findings provides views which can give the answers to the study topic.

The last research objective needs to do critical analyses of the impacts of bribery on various business sectors. The objectives need data analysis which helps the researcher in comparing the research outcome with previous reviews of literature on the topic so as to strengthen general outcome of research study. The research data shall therefore be gotten from documents that contain the reports on cases of corruption. The data includes the bribery cases that have been put to book by relevant authorities.

\subsection{Hypotheses}

Comparing different impacts of bribery on various business sectors in the economy is not an easy task. Bribery causes either positive impacts or negative impacts on businesses. The research expects to realize a different level of corruption and bribery in different firm sizes. Firms that require numerous licenses and documents in a corrupt country are more likely to engage in bribery than their counterparts in non-corrupt countries. The research aims at determining the truth of both claims. 


\section{ANALYSIS}

\subsection{Analysis on Firms}

Table 1: Difference in firms

\begin{tabular}{|c|c|c|c|c|c|c|}
\hline & $\begin{array}{l}(1) \\
\text { Sales } \\
\end{array}$ & $\begin{array}{c}\text { (II) } \\
\text { Productivity } \\
\end{array}$ & $\begin{array}{l}(\text { III }) \\
\text { Sales } \\
\end{array}$ & $\begin{array}{c}\text { (IV) } \\
\text { Productivity } \\
\end{array}$ & $\begin{array}{l}(\mathrm{V}) \\
\text { Sales } \\
\end{array}$ & $\begin{array}{l}(\mathrm{VI}) \\
\text { Productivity }\end{array}$ \\
\hline \multicolumn{5}{|c|}{$\begin{array}{l}\text { Panel A: Manufacturing and service firms } \\
\qquad \begin{array}{c}\text { Manufacturing } \\
\end{array}\end{array}$} & \multicolumn{2}{|c|}{ Construction } \\
\hline \multirow{2}{*}{$\begin{array}{l}\mathrm{N} \text { observations } \\
\text { Average bribery } \\
\text { mean effect }\end{array}$} & 88917 & 88960 & 442567 & 441964 & 96137 & 96402 \\
\hline & -6.99 & -3.95 & -1.08 & -3.57 & -3.74 & -5.05 \\
\hline $\begin{array}{l}\text { Average bribery } \\
\text { dispersion effect }\end{array}$ & -0.68 & -2.37 & 3.65 & 6.30 & 10.42 & 7.79 \\
\hline Average total effect & -7.67 & -6.32 & 2.57 & 2.73 & 6.68 & 2.74 \\
\hline
\end{tabular}

Panel B: By firm size: Micro, small and large firms

\begin{tabular}{lcccccc} 
& \multicolumn{2}{c}{$2-10$ employees } & \multicolumn{2}{c}{$11-49$ employees } & \multicolumn{2}{c}{$50+$ employees } \\
\cline { 2 - 7 } N observations & 291283 & 291513 & 228848 & 228688 & 107719 & 107728 \\
Average bribery & -0.76 & -2.79 & -3.80 & -3.79 & -6.78 & -5.04 \\
mean effect & 0.87 & 2.83 & 7.55 & 7.20 & 4.11 & 3.83 \\
$\begin{array}{l}\text { Average bribery } \\
\text { dispersion effect }\end{array}$ & 0.11 & 0.04 & 3.74 & 3.41 & -2.67 & -1.21 \\
\hline Average total effect & & &
\end{tabular}

Panel C: Stable, new-entrant, and exiting firms

\begin{tabular}{lcccccc} 
& \multicolumn{2}{c}{ Stable } & \multicolumn{2}{c}{ New entrants } & \multicolumn{2}{c}{ Exiting } \\
\cline { 2 - 7 } N observations & 101841 & 101859 & 212722 & 213066 & 28004 & 28072 \\
Average bribery & -4.36 & -2.79 & -2.93 & -5.29 & -9.69 & -5.63 \\
mean effect & 4.01 & 2.60 & 5.74 & 6.07 & 6.20 & 11.73 \\
$\begin{array}{l}\text { Average bribery } \\
\text { dispersion effect }\end{array}$ & -0.35 & -0.19 & 2.80 & 0.77 & -3.49 & 6.10 \\
Average total effect & &
\end{tabular}

\subsubsection{Different Types of Firms}

Table 1 gives the results of different businesses in the economy. The various sectors that have been studied are the manufacturing, construction, and services sectors all from panel A.

Table 2: Difference in firms

\begin{tabular}{|c|c|c|c|c|c|c|}
\hline & $(1)$ & (ㅍ) & (III) & (IV) & $(\mathrm{V})$ & $(\mathrm{VI})$ \\
\hline & Sales & Productivity & Sales & Productivity & Sales & Productivity \\
\hline \multicolumn{7}{|c|}{ Panel A: Manufacturing and service firms } \\
\hline & \multicolumn{2}{|c|}{ Manufacturing } & \multicolumn{2}{|c|}{ Services } & \multicolumn{2}{|c|}{ Construction } \\
\hline N observations & 88917 & 88960 & 442567 & 441964 & 96137 & 96402 \\
\hline $\begin{array}{l}\text { Average bribery } \\
\text { mean effect }\end{array}$ & -6.99 & -3.95 & -1.08 & -3.57 & -3.74 & -5.05 \\
\hline $\begin{array}{l}\text { Average bribery } \\
\text { dispersion effect }\end{array}$ & -0.68 & -2.37 & 3.65 & 6.30 & 10.42 & 7.79 \\
\hline Average total effect & -7.67 & -6.32 & 2.57 & 2.73 & 6.68 & 2.74 \\
\hline
\end{tabular}

Beginning with the manufacturing sector, there are high levels of bribery mean effects and also the bribery dispersion effects. Bribery means effects in manufacturing sectors tend to reduce the performances of the firms. The sales gotten from the manufacturing firms observably are low as compared to those from other sectors in the economy. The total average effects of bribery in the manufacturing sectors are -7.67. The negative sign implies that manufacturing sectors do not benefit much from the act of bribery in the corrupt environment. Manufacturing sector requires several legal documents so that it can be given a chance to operate. The increased numbers of the legal documents that are required imply that the firms in this sector should incur a lot of money in bribing to hasten the process of getting these documents. 
The service sector has some gains because of the effects of bribery. Even though the average bribery means effect displays a negative impact on these sectors, the average mean portrays a gain which is shown in panel $\mathrm{A}$ column III-IV from table 2. The growing of the service sectors makes it to be prone to the act of bribery. Positive gains from the service sectors are attributed to the reason that many of these service sectors are not so close to the greedy state servants and the decentralization of political power [4].
In conclusion, the sector as shown by table 2 , panel A, column V-VI has big gains in bribery environment. The big gain in their returns can be attributed to the activities which are related to bribe which happens in this sector. This involves the acquisition of permits and tenders which are required before starting of the construction and regulations that govern this sector.

\subsubsection{The Size of the Firms}

Table 3: Difference in firms

\begin{tabular}{|c|c|c|c|c|c|c|}
\hline & $(1)$ & (II) & (III) & $(\mathrm{IV})$ & $(\mathrm{V})$ & $(\mathrm{VI})$ \\
\hline & Sales & Productivity & Sales & Productivity & Sales & Productivity \\
\hline \multicolumn{7}{|c|}{ Panel B: By firm size: Micro, small and large firms } \\
\hline & \multicolumn{2}{|c|}{ 2-10 employees } & \multicolumn{2}{|c|}{ 11-49 employees } & \multicolumn{2}{|c|}{$50+$ employees } \\
\hline N observations & 291283 & 291513 & 228848 & 228688 & 107719 & 107728 \\
\hline $\begin{array}{l}\text { Average bribery } \\
\text { mean effect }\end{array}$ & -0.76 & -2.79 & -3.80 & -3.79 & -6.78 & -5.04 \\
\hline $\begin{array}{l}\text { Average bribery } \\
\text { dispersion effect }\end{array}$ & 0.87 & 2.83 & 7.55 & 7.20 & 4.11 & 3.83 \\
\hline Average total effect & 0.11 & 0.04 & 3.74 & 3.41 & -2.67 & -1.21 \\
\hline
\end{tabular}

Panel B of table 3 depicts bribery effects basing on the firm size. Basing on previous literature, smaller firms are not in a position to march the amount of money that is given as bribe by the large companies [2]. The large firms are known to have higher bargaining powers such that they can influence the state officials in an easy way in obtaining of the documents that are required for their various businesses.

The panel B of table 3 contains micro, small and large firms. Average bribery mean effects and average

bribery dispersion effects have same sign in all the three different sizes of the firms. Small businesses tend to get more in environments experiencing bribery because of the many exceptions that they get from the government. Small businesses get go a head from government as they are trying to promote entrepreneurship in local environments. Large firms irrespective will require a lot of permits so that they can operate.

\subsubsection{Firm Dynamics}

Table 4: Difference in firms

(ㅍ)

(III)

(IV) Sales Productivity

( $\mathrm{V}$ )

Sales Productivity Sales Productivity

Panel C: Stable, new-entrant, and exiting firms

\begin{tabular}{l|c|c|c|c|c|c|}
\hline & \multicolumn{3}{|c}{ Stable } & \multicolumn{2}{c}{ New entrants } & \multicolumn{2}{c}{ Exiting } \\
\cline { 2 - 7 } & 101841 & 101859 & 212722 & 213066 & 28004 & 28072 \\
\hline $\begin{array}{l}\text { N observations } \\
\text { merage bribery }\end{array}$ & -4.36 & -2.79 & -2.93 & -5.29 & -9.69 & -5.63 \\
\hline $\begin{array}{l}\text { Average bribery } \\
\text { dispersion effect }\end{array}$ & 4.01 & 2.60 & 5.74 & 6.07 & 6.20 & 11.73 \\
\hline Average total effect & $-\mathbf{0 . 3 5}$ & $-\mathbf{0 . 1 9}$ & $\mathbf{2 . 8 0}$ & $\mathbf{0 . 7 7}$ & $\mathbf{- 3 . 4 9}$ & $\mathbf{6 . 1 0}$ \\
\hline
\end{tabular}

Panel $\mathrm{C}$ in table 4 portrays different firms basing on their time in a bribery environment. The effect of bribery is generally felt by the firms that enters or exits the bribery environments [8]. This is attributed to the fact that firms which enter new market will require several permits so that they can operate. 


\subsection{Institutional Framework and Local Environment}

Table 5: institutional framework and local environment

\begin{tabular}{|c|c|c|c|c|}
\hline & $(\mathrm{I})$ & (ㅍ) & (III) & (IV) \\
\hline & Sales & Productivity & Sales & Productivity \\
\hline \multirow{2}{*}{ Bribery Mean } & -0.274 & -0.438 & -0.271 & -0.291 \\
\hline & $(0.014)$ & $(0.015)$ & $(0.011)$ & $(0.011)$ \\
\hline Bribery Mean* & 0.284 & 0.441 & & \\
\hline Rule of Law & $(0.020)$ & $(0.020)$ & & \\
\hline \multirow{2}{*}{ Bribery Dispersion } & 0.312 & 0.284 & -0.040 & 0.033 \\
\hline & $(0.019)$ & $(0.020)$ & $(0.015)$ & $(0.015)$ \\
\hline Bribery Dispersion* & -0.202 & -0.081 & & \\
\hline Rule of Law & $(0.027)$ & $(0.027)$ & & \\
\hline \multirow{2}{*}{ Rule of Law } & 0.822 & 0.181 & & \\
\hline & $(0.020)$ & 0.019 & & \\
\hline Bribery Mean* & & & 0.688 & 0.588 \\
\hline Bribery Dispersion & & & $(0.040)$ & $(0.040)$ \\
\hline N observations & 627634 & 626869 & 627546 & 626995 \\
\hline N group & 446004 & 445806 & 445726 & 445773 \\
\hline R2 within & 0.240 & 0.127 & 0.225 & 0.119 \\
\hline
\end{tabular}

\subsubsection{Local Bribery Environment}

Table 5 points out how different countries having different sectors respond to the action of bribery. According to these findings, higher average levels of bribery reduce the economic performance of firms operating in a bribery environment. From the result table 5 columns III-IV, the interactions between bribery means and bribery dispersion is quite significant. In local environments which fewer firms have bribery related activities can be very harmful to those firms which do not put it into practice majorly if there exist negative externalities which come with bribes. But in environments which all firms engages in bribery related activities, the degree of the damage caused to businesses shall be quite higher. Most firms shall incur an additional cost which comes with the act of bribing. This reduces the levels of investments in the country's economy. As a result of the lower levels of investment, these firms should not benefit from bribery activities.

\subsubsection{Difference in Institutional Framework of Countries}

The difference in framework of the institutions of a country determines the institutional strengths of the respective country. Countries with have weak institutions will tend to undergo higher levels of bribery on their business sectors which will undermine the performances of their firms in their general economy. The results from table 5 column I-II analyses how the local bribery environment has affected the performances of various businesses basing on the strengths of the countries' institutions.

\section{CONCLUSION}

Bribery is viewed as a big evil in a country's economy. From former studies which were carried out on effects of the act of bribery on various businesses portray that bribery has great harm to businesses as compared to general benefits [9]. Giving of bribe by various businesses leads to the reduction in the average amounts of investments. The levels of investment will be quite low because of general cost which was involved in the act of bribery. According to De Vaal, and Ebben, 2011, increased bribery activities in uneven local environments may cause smaller firms to be closed down because the larger firms rule and are better of through corruption. The larger firms will then have some unfavorable advantages because of their close connections to the political system. Larger firms shall receive special treatment from greedy officials of the government. Because smaller firms will not be able to march up the higher bargaining power of these larger companies, they will face a difficult business environment that will greatly hinder them and may eventually cause them to collapse. 
However, this research study has limitations which may hinder the outcome of quality results. Obtaining real information from this research topic shall be quite difficult since bribery is an illegal activity in most countries. There is also a lack of consistency in bribery data over the years. In addition, the information that will be used for research analysis may also be out of time. To do away with this, use of recent literature reviews helps in determining the accuracy of research information which has been provided from collected data.

\section{ACKNOWLEDGMENT}

I would like to extend my gratitude to my family for the continued support towards the success of this project and finalizing it within the limited time frame. I am very grateful for the school's continued support to ensure that we have a safe and comfortable learning environment despite the severity of the COVID-19.

\section{REFERENCES}

[1] Ackerly, B., \& True, J. (2010). Framework for research ethics and evaluation: justification and guidelines. Doing Feminist Research in Political and Social Science.

[2] Aterido, R., Hallward-Driemeier, M. and Pages, C. (2011). Big constraints to small firms' growth? Business environment and employment growth across firms, Economic Development and Cultural Change 59(3), 609-647

[3] De Vaal, A. and Ebben, W. (2011). Institutions and the relation between corruption and economic growth. Review of Development Economics 15(1), $108-123$

[4] Fan, C. S., Lin, C., \& Treisman, D. (2009). Political decentralization and corruption: Evidence from around the world. Journal of Public Economics, 93(1-2), 14-34.

[5] Hellman, J. S., Jones, G., Schankerman, M., \& Kaufmann, D. (1999). Measuring governance, corruption, and state capture: How firms and bureaucrats shape the business environment in transit. The World Bank.

[6] Hoffmann, F., Andersohn, F., Giersiepen, K., Scharnetzky, E., \& Garbe, E. (2008). Validation of secondary data. Strengths and limitations. Bundesgesundheitsblatt, Gesundheitsforschung, Gesundheitsschutz, 51(10), 1118-1126.

[7] Jensen, N. M., Quan, L. and Rahman, A. (2010). Understanding corruption and firm responses in cross-national firm-level surveys. Journal of International Business Studies 41(9), 1481-1504.
[8] Klapper, L., Laeven, L. and Rajan, R. (2006). Entry regulation as a barrier to entrepreneurship.

[9] MAURO, P. (2002). "The Persistence of Corruption and Slow Economic Growth." Working Paper of International Monetary Fund WP/02/213.

[10] Meon, P.-G. and Weill, L. (2010). Is corruption an efficient grease? World Development 38(3), 244259

[11] Perry, J., \& Felce, D. (1995). Measure for measure: How do measures of quality of life compare? British Journal of Learning Disabilities, 23(4), 134137.

[12] Prescott, A. (2008) Advantages and Disadvantages of Secondary Research [online] available from $<$ http://prosandconsofsecondaryresearch.blogspot.c o.uk/> [March 9 2016]

[13] Rontos, K., Vavouras, I., Ciommi, M. T., \& Salvati, L. (2019). Two faces of the same coin? A comparative, global approach to corruption and socioeconomic development. Quality \& Quantity, 53(4), 1875-1894.

[14] Hanoteau, Julien, and Virginie Vial. "Grease or Sand the Wheel? the Effect of Individual Bribes on the Drivers of Aggregate Productivity Growth." Journal of Indonesian Economy and Business, vol. 29, no. 1, Jan. 2014, pp. 1-16, doi:10.22146/jieb.6532.

[15] Blackburn, K., \& Forgues-Puccio, G. F. (2009). Why is corruption less harmful in some countries than in others? Journal of Economic Behavior \& Organization, 72(3), 797810. https://doi.org/10.1016/j.jebo.2009.08.009 